Insight, part of a Special Feature on Private Land Conservation - Landowner Motives, Policies, and Outcomes of Conservation Measures in Unprotected Landscapes

\title{
Public access to spatial data on private-land conservation
}

\author{
Adena R. Rissman ${ }^{1}, \underline{\text { Jessica Owley }}^{2}$, Andrew W. L'Roe $^{1}$, Amy Wilson Morris $^{3}{ }^{\text {and Chloe B. Wardropper }}{ }^{4}$
}

\begin{abstract}
Information is critical for environmental governance. The rise of digital mapping has the potential to advance privateland conservation by assisting with conservation planning, monitoring, evaluation, and accountability. However, privacy concerns from private landowners and the capacity of conservation entities can influence efforts to track spatial data. We examine public access to geospatial data on conserved private lands and the reasons data are available or unavailable. We conduct a qualitative comparative case study based on analysis of maps, documents, and interviews. We compare four conservation programs involving different conservation tools: conservation easements (the growing but incomplete National Conservation Easement Database), regulatory mitigation (gaps in tracking U.S. Fish and Wildlife Service's endangered species habitat mitigation), contract payments (lack of spatial data on U.S. Department of Agriculture's Conservation Reserve Program due to Farm Bill restrictions), and property-tax incentives (online mapping of Wisconsin's managed forest tax program). These cases illuminate the capacity and privacy reasons for current incomplete or inaccessible spatial data and the politics of mapping private land. If geospatial data are to contribute fully to planning, evaluation, and accountability, we recommend improving information system capacity, enhancing learning networks, and reducing legal and administrative barriers to information access, while balancing the right to information and the right to privacy.
\end{abstract}

Key Words: conservation easements; cost share; environmental governance; Geographic Information Systems; land trusts; privacy; privateland conservation; tax incentive; transparency

\section{INTRODUCTION}

Reliable and accessible information is necessary for effective environmental governance (Cash et al. 2006, Lemos and Agrawal 2006, Doremus 2008), including the governance of private lands (Morris and Rissman 2010, Owley 2015). The rapid spread of Geographic Information Systems and web-based maps have expanded opportunities for tracking spatial information relevant to conservation (Kearns et al. 2003). Yet information in the era of big data also entails potential risks, including the loss of privacy for landowners working with conservation entities such as government agencies and nonprofit organizations (Brin 1999). The right to information and the right to privacy are two "vital democratic values" that sometimes conflict (Halstuk and Chamberlin 2006). We focus on geospatial data related to privateland conservation, which has become a contested arena in which the tensions between privacy and transparency are shaping and limiting public access to maps of conserved lands. By geospatial, we mean data that has a locational (geographical) component; we are particularly interested in digital geospatial data. Conservation on private lands has grown rapidly and represents a substantial public investment (Morris 2008, Chang 2011). Despite technological advances that have enabled collection of extensive spatial data relevant to conservation, mapping of conservation actions on private lands has lagged behind mapping of protected areas in government ownership (Olmsted 2011, Baldwin and Leonard 2015). The reasons for incomplete, fragmented, or inaccessible spatial data on private-land conservation reflect the complicated politics of public information regarding private lands and the extensive capacity requirements for maintaining geospatial data.

Private-land conservation includes formal or informal approaches to conserving habitats, natural resources, recreation opportunities, open space (undeveloped land), or other conservation purposes on lands owned by private individuals, groups, or corporations. Private landowners are key decision makers for the lands they own, subject to existing land-use laws and other interests in the property. Most private-land conservation programs rely on voluntary enrollment (Bromley and Hodge 1990) although agreements and funding can originate from regulatory requirements. Government agencies and nonprofit land trusts play key roles in conserving privately owned land through conservation easements, cost-sharing, short-term agreements, leases, tax incentives, deed restrictions, regulations, and educational outreach to alter the behavior of private landowners (Doremus 2003).

We focus on geospatial data on the locations of four conservation tools: conservation easements, tax incentives, contract payments, and regulatory mitigation. Conservation easements are agreements between landowners and conservation easement holders (hereafter, "holders") in which landowners agree to restrictions on land use to achieve conservation purposes in exchange for payment, tax benefits, or development permits (Owley and Rissman 2016). Because they are property interests, conservation easements are publicly recorded along with other land records. Short-term agreements like cost-sharing and preferential property tax programs can be structured in several ways, including as contracts or permits. Incentive programs can be, but are not always, recorded as property interests, with enrollment periods of 1 to 50 years and varied penalties for early withdrawal (Hibbard et al. 2003). Private landowners and conservation organizations have a strong incentive to record property interests at local offices to prevent loss of those interests. Regulatory mitigation or exaction mandates the establishment of conservation agreements through the enforcement of legal requirements, in exchange for the right to destroy habitat, fill wetlands, or obtain zoning variances (Owley 2006).

${ }^{1}$ Department of Forest and Wildlife Ecology, University of Wisconsin-Madison, Madison, WI, ${ }^{2}$ SUNY Buffalo Law School, Buffalo, NY, ${ }^{3}$ The Trust for Public Land, San Francisco, CA, ${ }^{4}$ Nelson Institute for Environmental Studies, University of Wisconsin-Madison, Madison, WI 
Private-land conservation has grown rapidly. For instance, conservation easements held by local and state land trusts in the United States grew nearly fourfold between 2000 and 2010. However, the availability of maps of conserved land has lagged behind the rapid growth of digital mapping technologies. Building on prior research, we conceptualize geospatial information on private-land conservation in a broad social and environmental context (Fig. 1). Conservation agreements between landowners and conservation entities are intended to change landowner behavior in ways that improve environmental conditions (Rissman and Sayre 2012). Information about conservation agreements, behavior, and environments may be integrated through geospatial analysis and used by diverse actors.

Fig. 1. Conceptual framework for the role of spatial information in private-land conservation (modified from Rissman and Sayre 2012 with the addition of geospatial information). The underlying theory of change is that conservation agreements (policy outputs) change landowner behavior, which changes environmental conditions (environmental outcome), compared to what would have occurred without the conservation agreement. The green box surrounds the focus of this paper's four case studies: maps and attributes of conservation agreements.

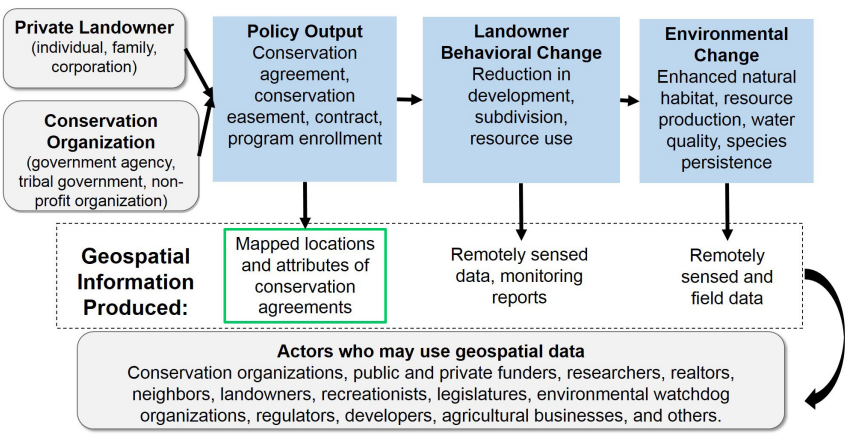

Information availability creates opportunities as well as concerns. Opportunities include the many ways that maps of conservation efforts on private lands can facilitate conservation planning, monitoring, and evaluation. Systematic conservation planning requires an understanding of what lands are already protected, and what the characteristics of those lands are, to invest efficiently in future conservation efforts (Margules and Pressey 2000, Rissman and Merenlender 2008). Spatial data can facilitate conserved area stewardship, including monitoring and enforcement of conservation agreements (Rissman and Butsic 2011). Maps of conservation programs can enable monitoring by multiple parties, including researchers, funders, neighbors, and government and nongovernmental conservation organizations (King and Fairfax 2006, Williams et al. 2006, Resource Renewal Institute 2015). Finally, spatial data are necessary for evaluating the effectiveness of conservation efforts (Byrd et al. 2009, Pocewicz et al. 2011).

Another rationale for tracking geospatial data is that it provides accountability for the public investment, involvement, and mitigation trade-offs that generate private-land conservation. Claassen (2014) reported that the 2014-2018 Farm Bill was set to offer US\$375 million annually in funding for the purchase and maintenance of conservation easements (down from the more than US\$710 million offered annually through the 2008-2012 Farm Bill). From 2008 to 2012, individuals claimed US $\$ 4.5$ billion in federal income tax deductions for donating conservation easements, for a total federal revenue loss of up to US $\$ 1.6$ billion (Liddell and Wilson 2008-2012). State tax programs that incentivize forest management and agriculture shift taxes to other property owners. The public investment is also high when lands are conserved as mitigation in exchange for the right to fill wetlands, take endangered species habitat, build in coastal areas, or conduct otherwise restricted actions (Owley 2006).

However, concerns about sharing spatial data on private-land conservation come from both landowners and conservation entities (Olmsted 2011). Conservation entities may not provide public access to information for several reasons including landowners' privacy concerns, capacity, legal restrictions, concerns about anticonservation use of the information, concerns about liability, or a preference for limiting public involvement. Landowner privacy concerns are salient to organizations because willing landowners make decisions about conservation adoption, land management, donations to conservation organizations, and political support for conservation (Rissman and Sayre 2012).

Privacy is an important value for many landowners. In Maine, landowners rated privacy as an important to very important reason to own land, regardless of their perspective on environmental conservation (Jansujwicz et al. 2013). A related landowner concern is that the release of spatial data may encourage trespassing or unlawful use of private property (Olmsted 2011). Trespassing and vandalism are among the top four concerns of private woodland owners (USFS 2015). Public access to maps of protected areas is essential for enabling recreation, but, in most states, only a minority of conserved private lands allow public recreation (NCED 2015a). Public recreation is a concern for many landowners who may be worried about privacy, trespassing, and vandalism (Butler et al. 2010, Snyder and Butler 2012). Olmsted (2011) notes a concern that public availability of spatial or locational data on a conservation easement may appear as permission for access to members of the general public.

Another landowner concern is that the accessibility of spatial data on their property will result in increased monitoring and restrictions on their behavior. In a survey of Iowa farmers, 30\% felt that collection of remotely sensed imagery for monitoring was an invasion of privacy (Arbuckle 2013). There is a disincentive for private landowners to allow data collection on their land because landowners may perceive that data collection may result in restrictions on land use through avenues such as the Endangered Species Act (ESA; Polasky et al. 1997). Even when endangered species do not exist on a property, mistakes in data collection or aggregation can sometimes negatively impact landowners (Huff 2015).

Aside from landowners, some conservation entities have concerns about making spatial data more readily available. Conservation entities may be concerned that public access to information would negatively impact the security of conservation values because trespassers might collect rare species or loot cultural resources (Wild et al. 2008). Conservation entities may also prefer to avoid 
Table 1. Characteristics of the four private-land conservation cases.

\begin{tabular}{|c|c|c|c|}
\hline $\begin{array}{l}\text { National Conservation } \\
\text { Easement Database (NCED) }\end{array}$ & $\begin{array}{l}\text { U.S. Fish and Wildlife Service } \\
\text { (USFWS) - Endangered Species } \\
\text { Act (ESA) }\end{array}$ & $\begin{array}{l}\text { U.S. Department of Agriculture } \\
\text { (USDA) - Conservation Reserve } \\
\text { Program (CRP) }\end{array}$ & $\begin{array}{l}\text { Wisconsin Department of } \\
\text { Natural Resources (WDNR) - } \\
\text { Managed Forest Law (MFL) }\end{array}$ \\
\hline $\begin{array}{l}\text { What conservation instrument is used? } \\
\text { Conservation easements }\end{array}$ & $\begin{array}{l}\text { Regulatory mitigation, resulting } \\
\text { in habitat conservation }\end{array}$ & Contract payments & Property-tax incentives \\
\hline $\begin{array}{l}\text { What type of organization is it? } \\
\text { Nonprofit organization }\end{array}$ & Federal government & Federal government & State government \\
\hline $\begin{array}{l}\text { What is the primary conservation organization? } \\
\text { The Trust for Public Land and } \\
\text { Ducks Unlimited aggregate } \\
\text { data from thousands of } \\
\text { conservation easement holders }\end{array}$ & USFWS & $\begin{array}{l}\text { USDA Farm Service Agency } \\
\text { implements; USDA Natural } \\
\text { Resources Conservation } \\
\text { Services develops conservation } \\
\text { plans }\end{array}$ & WDNR \\
\hline $\begin{array}{l}\text { What public benefits are provided? } \\
\qquad \begin{array}{r}\text { Natural habitat; open space; } \\
\text { water quality; public recreation }\end{array}\end{array}$ & $\begin{array}{l}\text { Biodiversity protection; natural } \\
\text { habitats; ecosystem protection }\end{array}$ & $\begin{array}{l}\text { Marginal land protection to } \\
\text { enhance water quality, flood } \\
\text { control, prairies, trees, wildlife, } \\
\text { and wetlands }\end{array}$ & $\begin{array}{l}\text { Regular timber production from } \\
\text { private forests, water quality and } \\
\text { soil conservation, public } \\
\text { recreation access }\end{array}$ \\
\hline $\begin{array}{l}\text { What does the public pay or lose for private-lan } \\
\qquad \begin{array}{r}\text { Millions } \$ \text { per year paid } \\
\text { through federal, state, and local } \\
\text { grants, and lost tax revenue }\end{array}\end{array}$ & $\begin{array}{l}\text { conservation? } \\
\text { Habitat losses due to } \\
\text { development are mitigated } \\
\text { through land conservation }\end{array}$ & $\begin{array}{l}\text { Public federal expenditures for } \\
\text { CRP in } 2014 \text { estimated at } \\
\text { US\$2.05 million }\end{array}$ & $\begin{array}{l}\text { State pays US } \$ 0.20 \text { per acre to } \\
\text { municipalities; } 80-95 \% \text { tax } \\
\text { reduction shifted to other } \\
\text { properties }\end{array}$ \\
\hline
\end{tabular}

external scrutiny from the media, funders, Congress, or Internal Revenue Service. However many conservation entities have shared geospatial data, and a remaining barrier is that some lack the technical and financial capacity to digitize property boundaries and make datasets available.

Capacity and the tensions between privacy and transparency shape conservation programs and access to information about those programs. We compare four private-land conservation programs in the United States involving conservation easements, contract payments, property tax incentives, and regulatory mitigation. These cases have a range of spatial data completeness and availability to the public. So far, little research has examined why some conservation efforts have more spatial data available than others. Specifically, we asked the following:

1. How available are spatial data on the locations of conserved lands?

2. Why do these private-land conservation programs vary in the level of spatial data available to the public?

3. What are the implications of spatial data (un)availability about these programs for key actors?

We discuss how findings from these cases can influence the development of geospatial data access on private-land conservation.

\section{METHODS}

We compared four cases to document the reasons the public can or cannot access spatial information on private-land conservation, and how that matters for relevant actors in each case. Our research questions and conceptual framework figure were influenced by background key informant interviews conducted between 2006 and 2009 by coauthor A. Morris with 86 land trust or government conservation program employees that included questions on public access to information about privateland conservation with an emphasis on conservation easements. We do not quote from these semistructured background interviews.

We selected four case studies to showcase prominent examples of private-land conservation policy instruments: conservation easements, contract payments, property-tax incentives, and regulatory mitigation (Table 1). The National Conservation Easement Database (NCED) is the largest compilation of spatial data on the conservation easements held by thousands of land trusts and government agencies. The U.S. Fish and Wildlife Service's (USFWS) species habitat mitigation under the ESA is one of the most prominent examples of regulatory mitigation that results in conserved private lands. The U.S. Department of Agriculture's (USDA) Conservation Reserve Program (CRP) is the largest source of contract or cost-sharing payments in the United States. The Wisconsin Managed Forest Law is considered among the most effective state property tax programs in the United States (Ma et al. 2014). The four cases include diverse conservation organizations, including two federal agencies, one state agency, and one multiorganization database with both nonprofit and government organizations. The cases varied in whether conservation organizations had compiled geospatial data, whether those data were available to the public, and whether data became more or less accessible to the public since the year 2000 . 
For each case study, we triangulated among multiple methods to answer our research questions. Coauthors were selected to contribute cases that represented important examples of spatial data access for each conservation instrument (conservation easements, contract payments, property-tax incentives, and regulatory mitigation). The authors have been researching each of the four private-land conservation programs for at least three years and have previously published spatial targeting, spatial planning, and policy and legal analyses on spatial data about each of the programs (Rissman and Merenlender 2008, Morris and Rissman 2010, Owley 2015, Wardropper et al. 2015, Owley and Rissman 2016, L'Roe and Rissman 2017). To answer the first research question on what spatial data are publicly available, we requested or downloaded available spatial data into a Geographic Information System for all four cases. Some aggregate GIS data on conserved private lands were available to download for three cases - conservation easements (NCED), contract payments (CRP), and property-tax incentives (MFL) - but not the regulatory mitigation (ESA) case (NCED 2015a, USDA 2016, WDNR 2016). For the MFL case, point data were available by download (WDNR 2016) while polygon data were available by request. We examined whether data were complete, publicly available, and at what spatial resolution.

To answer the second question on the reasons for varying levels of data availability and the implications for relevant actors, we conducted online searches, examined the text of relevant policies and laws, and examined news articles to understand stakeholder views on data access. We conducted semistructured interviews for each case to determine the reasons that data were or were not publicly available, and what the implications were for relevant actors. We started by contacting the primary staff person responsible for the program and its spatial data, and conducted snowball sampling to obtain contact information for other interviewees. For the NCED case, we conducted 11 phone interviews with NCED developers, land trusts, and government agency easement holders. In the ESA case, we conducted two phone interviews, communicated with six national and regional coordinators responsible for GIS and the species mitigation program by email, and contacted five California USFWS offices in person or by phone. For the MFL case, we conducted three phone interviews with current and former WDNR employees involved with the tax incentive program. For the CRP case, we conducted three phone interviews and one email interview with current or former NCRS, other USDA, University Extension, and Soil and Water Conservation District employees. We also interviewed one representative from a private landowner organization by phone. Interview transcripts were analyzed for key themes, and representative quotes were selected for each primary reason that spatial data were or were not publicly accessible.

\section{CASE STUDIES}

\section{Conservation easements: National Conservation Easement Database (NCED)}

NCED is a spatial database of conservation easements in the United States, including conservation easements held by private nonprofits, government agencies, and tribes. Conservation easements are held by thousands of organizations, including most of the 1700 land trusts in the United States (Chang 2011) as well as hundreds of local and state governments and several federal agencies. Conservation easements are often perpetual, passing from one landowner to the next. Conservation easements likely represent a significant portion of current land conservation efforts (Cheever and Owley 2015) yet access to the information regarding these properties is inconsistent.

NCED was established in 2009 and is managed by nonprofit organizations, mainly Ducks Unlimited and The Trust for Public Land. The database includes maps of conservation easements, reason for the creation of each conservation easement, date of conservation easement establishment, gap level (the level of habitat or biodiversity conservation), holder type, and landowner type. The goal is for NCED and the Protected Areas Database for the U.S. (PAD-US) together to provide a complete protected areas dataset for the United States. Prior to NCED, there was no comprehensive national effort to map and track conservation easements, though some states aggregated conservation easement data and the Conservation Almanac tracked and mapped public agency conservation easements. NCED funding has been about $75 \%$ from private sources such as the U.S. Endowment for Forestry and Communities and $25 \%$ from public sources such as federal land management and scientific agencies.

Regulatory mitigation: U.S. Fish and Wildlife Service (USFWS) habitat mitigation under the U.S. Endangered Species Act (ESA) Permanent conservation of endangered species habitat is one of the primary mechanisms used to mitigate impacts to listed species under the ESA. The permanence of this preservation is central to any argument that it effectively reduces harm to a species. Unfortunately, it is difficult to access spatial data for habitat mitigation lands and, therefore, difficult to determine whether these protected lands are meeting conservation purposes.

The ESA seeks to slow the extinction rate of fish, wildlife, and plant species and the destruction of their habitats. Generally, the act accomplishes these goals by identifying (and then listing) species as threatened or endangered $(\$ 4 b)$ and then both creating recovery plans for those species $(\$ 4 \mathrm{f})$ and preventing destruction of listed species and their habitat ( $\$ 7$ and $\$ 9)$. Because section 9 prohibits the taking of any listed species where take is defined to include physical harm to individuals as well as destruction of habitat in a way that causes harm to individuals, the Act imposes strict limitations on development (50 C.F.R. $\S 17.3$; Doremus 2003). Worried that the take prohibition would prevent desirable development, Congress added section 10 in 1982. Section 10 allows takes of listed species where the taking is incidental to an otherwise lawful activity, e.g., a new hospital building might kill endangered flies or destroy their habitat. In exchange for a permit allowing take, section 10 requires that developers mitigate for harm caused. Permit applicants must submit a Habitat Conservation Plan (HCP) that outlines, inter alia, the mitigation program. The HCP then becomes part of the permit and compliance with it is mandatory. Successful mitigation is vital for continued existence of impacted species. In nearly every case, the mitigation includes protecting habitat. The preservation plans often include conservation easements, but may also include deed restrictions or transfer of title to a conservation organization or local government (Owley 2015). 
Table 2. Public access to spatial data varied across four private-land conservation cases.

\begin{tabular}{|c|c|c|c|}
\hline $\begin{array}{l}\text { Conservation Easements: } \\
\text { National Conservation } \\
\text { Easement Database (NCED) }\end{array}$ & $\begin{array}{l}\text { Regulatory Mitigation: U.S. } \\
\text { Fish and Wildlife Service } \\
\text { (USFWS) - Endangered Species } \\
\text { Act (ESA) }\end{array}$ & $\begin{array}{l}\text { Contract Payments: U.S. } \\
\text { Department of Agriculture } \\
\text { (USDA) - Conservation Reserve } \\
\text { Program (CRP) }\end{array}$ & $\begin{array}{l}\text { Property-Tax Incentives: } \\
\text { Wisconsin Department of } \\
\text { Natural Resources (WDNR) - } \\
\text { Managed Forest Law (MFL) }\end{array}$ \\
\hline $\begin{array}{l}\text { Are spatial data complete? } \\
\text { No }\end{array}$ & No & Yes & Yes \\
\hline $\begin{array}{l}\text { Are property-level digital maps publicly availa } \\
\text { Partially }\end{array}$ & No & No & Partially \\
\hline $\begin{array}{l}\text { What spatial data are publicly available? } \\
\qquad \begin{array}{l}\text { 9.5 million of estimated } 16.2 \\
\text { million U.S. hectares mapped; } \\
\text { hundreds of conservation } \\
\text { organizations have not } \\
\text { contributed to the database }\end{array}\end{array}$ & $\begin{array}{l}\text { Large variation in data; plans } \\
\text { may have parcel data, parcel- } \\
\text { type descriptions, or no parcel- } \\
\text { level information. Maps rarely } \\
\text { in digital format }\end{array}$ & $\begin{array}{l}\text { More than } 10.1 \text { million hectares } \\
\text { enrolled in CRP in 2014, but } \\
\text { only summary statistics } \\
\text { aggregated at county level are } \\
\text { publicly available as of } 2008\end{array}$ & $\begin{array}{l}\text { Over } 0.4 \text { million hectares allowing } \\
\text { recreational activities listed online } \\
\text { by county and in online map; } \\
\text { land closed to public recreational } \\
\text { access is not viewable online }\end{array}$ \\
\hline $\begin{array}{l}\text { Who decides level of spatial data? } \\
\text { Primarily the conservation } \\
\text { easement holders }\end{array}$ & $\begin{array}{l}\text { National and local USFWS } \\
\text { offices, with permittees }\end{array}$ & 2008 Farm Bill, Section 1619 & WDNR \\
\hline
\end{tabular}

\section{Contract payments: U.S. Department of Agriculture (USDA) - Conservation Reserve Program (CRP)}

$\mathrm{CRP}$ is a cost-share and rental payment program that incentivizes farmers to convert environmentally sensitive land from agricultural production to vegetative cover. CRP was authorized by the Food Security Act of 1985 and is administered by the USDA's Farm Service Agency, with consultation and management planning by the USDA Natural Resources Conservation Service (NRCS). The primary purposes of this program are to conserve soil, protect water quality by preventing runoff, and provide long-term wildlife habitat. The conservation mechanism is a $10-15$ year voluntary contract in which USDA pays landowners to maintain vegetative cover rather than crops; the payment rate is specific to each county, based on soil productivity and average rent per acre.

\section{Property-tax incentive: Wisconsin Department of Natural Resources (WDNR) - Managed Forest Law (MFL)}

Every U.S. state supports private forest land ownership and management by reducing annual property taxes for participating forest landowners (Hibbard et al. 2003). Wisconsin's MFL and preceding Forest Crop Law (FCL) are considered among the most effective state programs in protecting forests highly susceptible to development (Ma et al. 2014). Both MFL and FCL tax incentive programs are administered by the WDNR primarily to encourage timber production and sound forestry practices on private lands (Rickenbach et al.2005), with a growing recognition of nontimber public benefits (Locke and Rissman 2012) including the provision of public recreational access. Public access for hunting and fishing was available on all lands enrolled in the FCL program from 1927 to 1985 . Since 1987 , the MFL program has allowed owners to select whether to open their land for public outdoor activities including hunting, fishing, hiking, sight-seeing, and skiing for an additional tax reduction. In 2016, public recreation access was allowed on $18 \%$ of forest land (199,100 open hectares) enrolled by small landowners (those with under 404 hectares), compared to $97 \%$ of land $(289,300$ open hectares) enrolled by large landowners. Recreationists are not required to get permission from enrolled landowners before accessing land, though it is strongly encouraged.

\section{RESULTS}

Accessibility of private-land conservation records

Public access to spatial data varied across the four private-land conservation cases we examined (Table 2). The thousands of conservation-easement-holding organizations are beginning to fill in the NCED map. USFWS does not have consistent spatial records on HCPs and lands conserved through habitat mitigation. Both the CRP and the MFL cases have complete spatial data internally, but only MFL provides all its data by request in GIS format and provides data on lands open to recreation in an online portal. CRP spatial data sharing is restricted by law.

Conservation easements (NCED)

Only an estimated $55 \%$ of known conservation easement lands have been mapped, on 9.5 of 16.2 million hectares; 16.2 million hectares is a conservative estimate of the total area under conservation easement (NCED 2014). Among those conservation easements mapped in NCED, $93 \%$ of the spatial boundaries of the conservation easement properties were available for public download, $5 \%$ had spatial data withheld from public and $2 \%$ had spatial data viewable online but not available for download in 2015. The hundreds of land trusts and governments that did not contribute spatial data to NCED may face capacity barriers in producing digital maps, may not have been contacted to contribute, or may have concerns about releasing information on private lands. Unlike the PAD-US, which is housed in the U.S. Geological Survey, NCED is not subject to the Freedom of Information Act (NCED 2015b).

Regulatory mitigation (ESA)

The USFWS does not maintain a geospatial database of properties conserved as a result of HCP mitigation. It is challenging to determine the location of conserved land or 
mitigation projects associated with the $809 \mathrm{HCPs}$ or HCP amendments as of 2016. USFWS does not hold the conservation easements protecting HCP mitigation lands and does not have a list of the nonprofit and government agencies holding conservation mitigation lands. It would be a Herculean feat even to determine how many hectares of private land are encumbered with conservation easements or deed restrictions associated with the ESA. The nonprofit or government holders of mitigation lands may have contributed spatial data to NCED or PAD-US, but there is no way to connect maps of those conserved lands to HCP mitigation. The USFWS does not have a uniform approach to forming or recording mitigation projects. The agency maintains a web site of projects, Environmental Conservation Online System (ECOS), but very few of the project entries contain information about mitigation. A new data standard has been developed to map planning area boundaries but not the conserved or impacted/take lands (USFWS 2016). Some records contain maps identifying potential or proposed mitigation lands, but where maps are included, they are PDFs rather than shapefiles, and the parcels are not always easily locatable. Moreover, they may not represent the final sites of mitigation projects. There is no requirement that USFWS compile spatial data regarding mitigation land, let alone make it available to the public. At least one local California USFWS office has been requiring applicants (developers) to submit GIS files of the HCP boundaries and conserved and impacted/take lands.

In a study of endangered species mitigation plans in California, Owley (2015) found that it was often challenging to learn the basics of the mitigation plans. In some cases, it was not possible to locate the mitigation sites after contacting the USFWS office, while other offices had paper records of spatial and descriptive data available. In other cases, the mitigation locations were discoverable, but obtaining the conservation agreements with information on land-use restrictions required an in-person visit to a county land recorder's office where the materials were sometimes still difficult and expensive to locate (Morris and Rissman 2010, Owley 2015).

Contract payments (CRP)

The USDA Economic Research Service collects and reports data on CRP enrollment aggregated by county, available on its web site for public download as text and geospatial files, and with an online mapping tool (USDA 2016). CRP data include year of enrollment, acres enrolled, payments per enrolled acre, and date of contract expiration. USDA maintains farm field-level GIS data but they are not publicly available. However, CRP data at the property level were available for 2007.

The 2008 version of the Farm Bill, the primary funding source for soil, water, rangeland, and forest conservation, eliminated public access to parcel-level data about lands enrolled in CRP (Steinzor and Huang 2012). Since then, data on CRP have been aggregated at the county level; the public is not given access to any data at the subcounty level. Access to the conservation practices information and the geospatial Common Land Unit (field boundaries of farms in the United States) is available to Conservation Cooperators such as other federal agencies like the U.S. Geological Survey and state conservation agencies through a signed agreement with NRCS and/or the Farm Services Agency (Hively et al. 2013).
Property-tax incentives (MFL)

Ownership and location information for MFL-enrolled properties open to recreation have been available for decades on commercially produced county plat maps and printed lists available at county register of deeds offices. In 2012, the WDNR announced the launch of an online mapping application that provides the general location of enrolled properties open to recreation along with landowner contact information. Although properties are only visible on the map as points, there are links to more detailed boundary and timber stand maps, which can be downloaded individually. Information can be located by zooming in to a particular location, but is not searchable by other associated information like owner name or forest type. Shapefiles of the approximate location for all enrolled properties are available for download from the WDNR website and more detailed ownership information is available to researchers upon request (L'Roe and Rissman 2017). The locations of open forest land have also been incorporated into commercially available applications for mobile phone, tablet, and GPS products.

\section{Reasons spatial data are (not) accessible and why it matters}

The current state of public access to spatial data on private-land conservation is driven by organizational capacity in some cases and privacy concerns in others (Table 3 ). The potential for the use of spatial data, and the implications of not having access to these data, depend on the broader context of actor interests as shown in the Figure 1 conceptual framework.

\section{Conservation easements (NCED)}

According to interviewees, NCED is incomplete because of (1) capacity constraints on digitizing and compiling data and (2) reluctance of conservation organizations to contribute information. Maps of conservation easements have traditionally varied in their accessibility to the public because they are held by thousands of organizations with different data-sharing policies; central records have been required by only a handful of state governments; and federal policies have not required centralized spatial records. NCED has been successful in compiling many conservation easement maps. It increased the funding and technical expertise for compiling conservation easement digital maps, with coordinator nonprofit organizations (currently Ducks Unlimited and The Trust for Public Land) contacting many conservation easement holders. Capacity remains a limitation, however. Many holders do not have digital records, and NCED has limited resources for digitizing conservation easements, even when holders are willing to share them. Furthermore, many holders have not been contacted directly or repeatedly. Many nonprofits and some government agencies have also declined to contribute records of their conservation easements to NCED. NCED staff reported that holder concerns with landowner privacy were a primary reason they gave for declining to participate. When asked about public access to information on conservation easements, one private landowner representative who works on conservation said, "it's a minefield ... for most people, especially outside the northeast, privacy is the number one factor. Dissemination can be more damaging than helpful." Other reasons that conservation organizations gave for declining to participate in NCED included fear that conservation easement data could be used as a target for developers (because those properties may be undervalued on the market), prior agreements with landowners not to share locations, and power dynamics or competition among conservation organizations. 
Table 3. Reasons spatial data are (or are not) publicly accessible in each program, based on document review and interviews. Quotes describe why data are (or are not) publicly accessible and the implications of the current level of information access. Cases are conservation easements in the National Conservation Easement Database (NCED), regulatory mitigation under the Endangered Species Act (ESA), contract payments under the Conservation Reserve Program (CRP), and property-tax incentives under Wisconsin's Managed Forest Law (MFL).

\begin{tabular}{|c|c|c|c|c|c|}
\hline & NCED & ESA & CRP & MFL & Quote \\
\hline \multicolumn{6}{|c|}{ Reasons spatial data are not publicly accessible } \\
\hline $\begin{array}{l}\text { Lack of financial and } \\
\text { technical GIS capacity }\end{array}$ & Yes & Yes & No & No & $\begin{array}{l}\text { "We don't have the funding to contact everyone to get the data or digitize } \\
\text { the data for them." (NCED developer) }\end{array}$ \\
\hline $\begin{array}{l}\text { Concern about } \\
\text { landowner privacy }\end{array}$ & Yes & No & Yes & Partly & $\begin{array}{l}\text { "Clearly the concern is about private landowners and their feelings about } \\
\text { privacy" (Land trust employee) }\end{array}$ \\
\hline & & & & & $\begin{array}{l}\text { "No USDA information can be released to any individual or entity... when } \\
\text { the information will be used for enforcement purposes." (NRCS 2011) }\end{array}$ \\
\hline $\begin{array}{l}\text { Concern about negatively } \\
\text { impacting conservation } \\
\text { values }\end{array}$ & $\begin{array}{l}\text { Slight } \\
\text { concern }\end{array}$ & $\begin{array}{l}\text { Slight } \\
\text { concern }\end{array}$ & No & $\begin{array}{l}\text { Slight } \\
\text { concern }\end{array}$ & $\begin{array}{l}\text { "[The online map] probably caused some people to change their land to } \\
\text { closed who may not have realized the land was open." (former WDNR } \\
\text { employee) }\end{array}$ \\
\hline $\begin{array}{l}\text { Legally prohibited from } \\
\text { sharing information }\end{array}$ & Rarely & No & Yes & No & $\begin{array}{l}\text { "You're concerned as an individual that if you release something, the } \\
\text { hammer is going to come down on you because } 1619 \text { is a very broadly } \\
\text { worded prohibition against the release of information." (former USDA } \\
\text { employee) }\end{array}$ \\
\hline \multicolumn{6}{|c|}{ Reasons spatial data are publicly accessible (for the two cases with property-level public geospatial data) } \\
\hline $\begin{array}{l}\text { Enable conservation } \\
\text { planning }\end{array}$ & Yes & $\mathrm{n} / \mathrm{a}$ & $\mathrm{n} / \mathrm{a}$ & No & $\begin{array}{l}\text { "For a planning tool to be useful, you would want all the information } \\
\text { there." (NCED developer) }\end{array}$ \\
\hline $\begin{array}{l}\text { Evaluate conservation } \\
\text { holdings }\end{array}$ & Yes & $\mathrm{n} / \mathrm{a}$ & $\mathrm{n} / \mathrm{a}$ & No & $\begin{array}{l}\text { "Evaluate and monitor HCP success: Standards [for spatial data] help both } \\
\text { the Service and cooperators monitor conservation activities progress and } \\
\text { make adjustments as needed." (USFWS 2015) }\end{array}$ \\
\hline $\begin{array}{l}\text { Account to funders and } \\
\text { taxpayers }\end{array}$ & Yes & $\mathrm{n} / \mathrm{a}$ & $\mathrm{n} / \mathrm{a}$ & Yes & $\begin{array}{l}\text { Farm Bill } 1619 \text { "makes it impossible to assess the efficacy of the hundreds } \\
\text { of millions of dollars that the U.S. taxpayer spends on conservation." } \\
\text { (former USDA employee) }\end{array}$ \\
\hline Enable public recreation & No & $\mathrm{n} / \mathrm{a}$ & $\mathrm{n} / \mathrm{a}$ & Yes & "The bulk of the map use is by hunters." (WDNR employee) \\
\hline $\begin{array}{l}\text { Showcase conservation } \\
\text { efforts }\end{array}$ & Yes & $\mathrm{n} / \mathrm{a}$ & $\mathrm{n} / \mathrm{a}$ & No & $\begin{array}{l}\text { "[MFL open land locations] were always available, but we never really } \\
\text { publicized them." (WDNR employee) }\end{array}$ \\
\hline
\end{tabular}

NCED describes some of the benefits of the database as demonstrating the need for conservation, raising the profile of conservation organizations, improving planning and strategic acquisitions, preventing incompatible uses like the siting of federal power lines, and contributing to accountability including easement monitoring (NCED 2015b). The actual use of NCED information is difficult to track.

\section{Regulatory mitigation (ESA)}

There are no specific legal requirements regarding the availability or format of information on mitigation plans under the federal Endangered Species Act. The statute requires that applicants for incidental take permits under section 10 detail how they will "minimize and mitigate" the projects' impacts on protected species $(\S 10(\mathrm{a})(2)(\mathrm{A})(\mathrm{ii}))$ and it requires that such plans be made available for public comment $(\S 10(\mathrm{a})(2)(\mathrm{B}))$. After permit issuance, the final permits and plans are also available to the public (although sometimes they are not readily accessible and can only be obtained via Freedom of Information Act [FOIA] requests). USFWS has also issued an agency guidance document (a policy document without the force of law) regarding habitat conservation planning in the form of the HCP Handbook. The Handbook emphasizes the case-by-case approach to HCPs and indicates that each field office can adopt its own approach with guidance from the regional office. There are eight regional offices and over one hundred field offices that process permits, each potentially organizing and collecting data in its own way. The mitigation plans are written by applicants (developers) in consultation with the USFWS increasing again the variability of data format and quality. Even where the actual conservation plans detailing mitigation plans are available, there is no statutory requirement regarding the format of the information or the level of detail required. Anecdotal evidence suggests that most mitigation projects involve conservation easements and deed restrictions.

The reason given by interviewees that the agency has not compiled the records in the absence of a legal mandate is a lack of capacity and priority in the agency to compile records on HCPs and the resulting conserved and impacted/take lands. USFWS has detailed records of its own real estate interests and has high capacity for land records management; however, the public land program is not integrated with the endangered species mitigation program. Data collection is further challenged because the property interests are held by numerous state agencies and nonprofit land trusts.

The ESA is enforceable by members of the public (who can show standing). Without access to mitigation data, however, one cannot determine whether the mitigation plans are being complied with. Members of the public interested in enforcing the terms of the HCP permit would be hampered in doing so if they cannot obtain 
details or data on mitigation projects. Information about current conservation efforts can be useful for coordinated efforts at species and ecosystem protection. This is not to say that this information is never available, but rather it is inconsistent in its availability, format, and quality. Agency staff suggested that privacy concerns by applicants were not a driving factor in restricting information access, and that most of what is compiled already in the ECOS database is available to the public.

\section{Contract payments (CRP)}

Access to spatial data is restricted by the 2008 Farm Bill, Section 1619 (U.S. Congress 2008). Section 1619 prohibits the release of any geospatial data collected from beneficiaries of Farm Bill programs unless the data have been "transformed into a statistical aggregate" or in the case that the Department of Agriculture is responding to a "disease or pest threat to agricultural operations." It states that USDA and partners "shall not disclose: (A) information provided by an agricultural producer or owner of agricultural land concerning the agricultural operation, farming or conservation practices, or the land itself, in order to participate in programs of the Department; or (B) geospatial information otherwise maintained by the Secretary about agricultural land or operations for which information described in subparagraph (A) is provided." USDA may disclose protected information to a Conservation Cooperator when the Cooperator is "providing technical or financial assistance with respect to the agricultural operation, agricultural land, or farming or conservation practices."

According to one news report, the Section 1619 amendment was advanced by livestock industry lobbyists when the Farm Bill went to conference (SEJ 2009). The provision was framed as a response to Multi Ag Media LLC v. Dep't of Agriculture (515 F.3d 1224 [D. C. Cir. 2008]). In this case, Multi Ag Media LLC, a commercial vendor of agricultural data that markets to dairy farmers, made FOIA requests for records including geospatial records. USDA declined to provide geospatial data, invoking FOIA Exemption 6 , which protects individual privacy interests in government records. USDA lost in court and provided 2007 GIS data at the farm field level. The court determined that the public interest in disclosing the information outweighed the privacy interests of agricultural producers. With the subsequent amendments to Section 1619, property-level of geospatial information has not been publicly available since 2007, except to Conservation Cooperators. Conservation easement boundaries are not included under the 1619 restriction, so USDA does share the locations of its conservation easements.

Lack of information impacts governments, nonprofits, and citizen groups. At the state level, conservation agency employees may be forced to work with information that is aggregated at the county level, when their planning occurs on a watershed scale. In 2011, a Nebraska Natural Resources District lost their appeal to obtain geospatial data from USDA (Central Platte Nat. Resources Dist. v. U.S. Dep't Agriculture, 643 F.3d 1142 [8th Cir. 2011]). Citizen watershed groups are also hampered by the inability to track the progress of their efforts. The results of any edge-of-field monitoring conducted by NRCS on CRP lands - valuable information on the contribution of individual parcels to watershed-wide water quality degradation - are not available to nongovernmental watershed groups.
Property-tax incentives (MFL)

The Wisconsin MFL program has maintained general location information primarily to allow for long-term planning for timber production, enforcement of program requirements and tax benefits, and as a way to track the enrollment of the land as it changed ownership. The move to make spatial data available in a more accessible online format was driven by media and political pressure to allow citizens to make use of the recreation rights to enrolled properties. In September 2012, investigative reporting by a major newspaper demonstrated the difficulty of identifying and locating open MFL-enrolled forest land (Rutledge 2012). That article, which included video demonstrating the challenges of finding land information and access routes, was spurred by citizen concerns about enrolled forest land receiving tax reductions without actually providing access. At the direction of the state governor and support of lawmakers from both major political parties, the WDNR responded by quickly putting staff and resources toward making information available before the fall deer-hunting season of 2012. In late October of 2012 the WDNR announced the launch of an online "Private Forest Lands Open for Public Recreation" web mapping application to allow citizens to locate enrolled properties and owner contact information.

Evidence of the actual use of MFL tax program information is difficult to track, but the provision of spatial data has opened numerous possibilities. The most common users are recreational hunters, for whom land availability is a major challenge, to identify and locate private land open to public hunting access. The map has also been used by hikers, skiers, and bird-monitoring organizations. There is now an increasing push by loggers and foresters to map all properties, including those that are closed to public access, to allow contractors to identify properties with approaching deadlines for required timber harvesting and those also enrolled in forest certification programs. Academic researchers have used the MFL spatial information for peerreviewed publications on hunting pressure context (Dubay et al. 2015, Olson et al. 2015) and to examine the contribution of tax program enrollments to forest connectivity with public lands (Locke and Rissman 2012).

\section{DISCUSSION}

Spatial data in the "information age" can enhance environmental protection and natural resource management by filling information gaps and reducing uncertainty (Esty 2004). Public funds, tax incentives, and environmental regulations all help conserve private lands. Spatial data can contribute to planning, evaluation, and public accountability for these programs. Yet spatial data can also create privacy concerns for landowners and challenge the capacity of underfunded conservation organizations. As information is increasingly easy to create and share, policy makers have had to grapple with what data to make available in what forms and to whom (Hartter et al. 2013). Spatial information use and availability varies with conservation programs' social and ecological contexts, as depicted in Figure 1. The political and social dynamics of geospatial mapping are widely debated because maps have important roles in influencing ontology (what is), norms (what is expected), and social power (Pickles 2004).

Spatial data on private-land conservation are accessible or inaccessible for different reasons. Neither the contract payments (CRP) nor regulatory mitigation (ESA) programs make spatial 
data on conserved lands available. CRP spatial data exist, but data sharing is restricted by the 2008 Farm Bill. USFWS data on habitat mitigation are limited by the agency's lack of capacity for centralized record-keeping. In contrast, NCED is managed by a private, nonprofit partnership that has stepped in to try and fill an enormous gap in public information by compiling conservation easement data from thousands of nonprofit organizations, cities, counties, states, and federal agencies. Incomplete data on conservation easements reflects the decentralization of environmental governance to nonprofit organizations, cities, and counties, in addition to state and federal natural resources agencies. Unique among these cases, the Wisconsin natural resources agency has relatively robust spatial data on its state forestry tax program aggregated to the quarterquarter (16.2 hectare) level and available in GIS format by request and mapped online for those lands open to public recreation.

These findings reflect a complex, inconsistent, and overall incomplete spatial data record on private-land conservation. These inaccessible records can be contrasted with the relatively complete records in the Protected Areas Database (PAD-US) for U.S. public lands. Globally, spatial information has been faster to develop for parks and public protected areas than for privateland conservation. For instance, the World Database on Protected Areas started information collection in 1981 and its primary focus has been on public lands, though the International Union for the Conservation of Nature (IUCN) is considering expanding maps of private protected areas.

The availability of spatial data varies with legal requirements and administrative tools. Governments have undertaken major efforts to increase public information access. For instance, the U.S. federal government has developed https:/www.data.gov/ to increase public data transparency on a range of issues from student loan program data to health care provider costs. Geospatial data are increasingly accessible via online mapping tools and downloadable GIS data. Spatial land records with parcel boundaries linked to assessors' data on housing are increasingly available, following the work of the Federal Geographic Data Committee, although data availability varies considerably by state and county (Von Meyer 2004). Conservation program records also contrast with the large amount of private property information available through property records at county recorder's offices, some of which is readily accessible through real estate websites, and provided to commercial agriculture businesses.

Reliable and accessible geospatial information is helpful for making natural resource management decisions for conservation planning, monitoring, and evaluation (Biber 2011). Spatial data on enrollment in private-land conservation programs is an important data stream for the application of digital technology to conservation, or "digital conservation" (van der Wal and Arts 2015). Facilitation of fine-scale mapping is important because it can improve conservation targeting and understanding of smallscale environmental outcomes (Margules and Pressey 2000, Owen 2013, Wardropper et al. 2015). To track the status and trends in conserved private lands, it would be beneficial to link spatial data with remote sensing or scientific monitoring information. Using such information requires archiving and clear methods for data access (Doremus 2008). However, scientific monitoring records from private lands, such as USDA Forest Inventory and Analysis, are also often inaccessible at fine scales (Sabor et al. 2007).

Concerns about landowner privacy on private property are a driving factor behind restrictions on data availability, in addition to lack of capacity for mapping. For instance, in California, landowner concerns prompted the removal of a provision in a conservation easement indexing bill that would have required the reporting of locational data on easements (Morris and Rissman 2010). The feedback loop that connects information to landowners is one of the complicating factors for tracking privateland conservation. Landowners serve important roles as land stewards but sometimes also as developers or polluters whose current or future decisions may run counter to conservation goals. Meanwhile, conservationists are wary of igniting a politicized debate about private property rights. The property rights movement is critical of government and environmentalism (Jacobs 1995) and critiques of private-land conservation as government intrusion on private property rights have started to emerge (Gattuso 2008). Conservationists must consider social perceptions of new technology and information systems in order to appeal to rural landowners (Sandbrook 2015).

\section{Potential policy changes}

Changes in information availability would be needed to support strategic planning, evaluation, and accountability for private-land conservation (Rissman and Smail 2015). We make several recommendations that would improve public access to information on private-land conservation, while addressing concerns about privacy. First, we call for increased conservation organization capacity for mapping. Capacity, including funding and trained personnel, is particularly lacking in small land trusts, some local governments, and perpetually underfunded government agencies like the USFWS. Governments, foundations, and other conservation organizations could increase financial and technical assistance for compiling and digitizing records. NCED will require increased and ongoing funding to complete the conservation easement database. In the case of habitat mitigation, we recommend that USFWS maintain a GIS of all conserved and lost (taken) mitigation properties, including details regarding property interests and agreements by nonprofit organizations and local and state government agencies (Owley 2015). In this case, capacity is the main barrier and the public interest is high in ensuring endangered species protection after take is allowed.

Although federal spending is expected to be more transparent and integrated under the Digital Accountability and Transparency Act of 2014, additional reforms would be needed to link spending to geospatial conservation outcomes and the current law does not place spatial data requirements on recipients of federal aid. Conservationists, stakeholders, and researchers need information systems that can track the complex multiagency responsibilities shared among government, nonprofit, and sometimes for-profit entities in conservation deal making (Fairfax et al. 2005), involving both fee-simple acquisition and diverse conservation agreements on private lands.

Safeguards could reduce the privacy concerns of private landowners. Social acceptability of information systems is an important value and conservation information systems may be better received if they are sensitive to landowner privacy concerns. 
For instance, lands closed to public recreation can be clearly marked. In some cases, certain sensitive lands may be available in GIS form without permission to publish, or as centroids rather than polygons, but may not be available online. Although this limits transparency and analysis and creates an "epistemic asymmetry" between conservation organizations and the public (Oksanen and Kumpula 2013), it may be appropriate for a small proportion of properties with sensitive conservation or cultural values. As geospatial technologies advance, there is some uncertainty about how data may become used in the future. Future research should examine the effects of geospatial data availability including the emergence of risks to landowners and impacts on conservation values.

Second, we suggest that geospatial data would be more beneficial for planning and evaluation if it were better integrated in information networks to increase learning (Olsson et al. 2004). Information is useful for organizations and citizens when it increases learning, including social learning through informal networks and formal learning forums (Moynihan and Landuyt 2009). Simple disclosure may not necessarily increase accountability because large datasets can be difficult to comprehend and require technical skills. Instead, we suggest the need to make data available in forms that are both aggregated to relevant planning scales like states or watersheds, and propertyscale for use in GIS analysis and modeling with other social and environmental data (Morris and Rissman 2010). Matching the scales of conservation action and information use would help bridge landscape-scale conservation planning with property-scale agreements.

Third, there are potential approaches for reducing legal and administrative barriers to information access. Transparency and accountability are stated needs throughout U.S. government. Because the Farm Bill is one of the single largest funders of conservation on private lands, future Farm Bill provisions or agency regulations that enable geospatial data sharing on lands enrolled in Farm Bill programs would have a major impact on planning, evaluation, and accountability. Debates over the provisions of future Farm Bills should tackle the pressing question of how to balance the benefits of data access for multiple stakeholders with farm privacy concerns. Issues for discussion include who should have data access, to what databases, for what purposes, with what restrictions on data republishing, and at what spatial scale. Farm Bill programs use large sums of public money, so there is a corresponding need to account for expenditures to the public. Spatially explicit data can make the biggest contribution to agricultural, natural resources, and environmental quality planning, for instance the ability to examine conservation practices in small watersheds. Full access to CRP spatial data would provide the greatest potential for planning, coordination, and evaluation. Given the concern over uses of CRP data in Multi Ag Media LLC v. Dep't of Agriculture, perhaps data use for marketing to farmers could be restricted. An option for more limited data availability would allow researchers to obtain authorization to access (but not distribute) farm-specific data for research purposes, as is possible for other government data.

Private-land conservation data access could also be better connected to the ongoing discussion of transparency, privacy, and security of agricultural data. For instance, the Global Open Data for Agriculture and Nutrition (GODAN), created at the 2012 G-8 Summit, has the purpose "to support global efforts to make agricultural and nutritionally relevant data available, accessible, and usable for unrestricted use worldwide" (GODAN 2017). In contrast to the growing restrictions on public access to farm data, considerable information is being made available to companies that provide agriculture technology. To ensure that contract terms are transparent to farmers, the Farm Bureau developed an Ag Data Transparent Seal with core principles established in 2016 that provide for company data access with assurances for farmer education, consent, and notification of contract terms (American Farm Bureau Federation 2017). One principle states "we believe farmers own information generated on their farming operations. However, it is the responsibility of the farmer to agree upon data use and sharing with the other stakeholders with an economic interest." The broader economic context for data access shapes transparency in both agriculture and private land conservation.

For conservation entities, incentives or requirements to contribute data on their holdings to databases such as NCED could potentially be advanced through the land trust standards and practices, land trust accreditation, state and federal funding requirements for purchases, and state or federal government requirements for tax deductible conservation easements. National databases of property tax incentive program enrollments could help expand comparative learning about state programs.

In conclusion, private-land conservation is implemented and monitored within broader social and ecological contexts. Through cases of government and nongovernmental conservation, we have demonstrated how the right to information and the right to privacy come into tension in mapping private lands. Information availability is in flux, under pressure both from private landowners concerned about privacy and from funders and beneficiaries concerned about effectiveness and accountability. Geospatial data would be improved by increasing capacity for data compilation and maintenance, developing information networks that enhance learning, and reducing legal and administrative barriers that hamper access to information.

Responses to this article can be read online at: http://www.ecologyandsociety.org/issues/responses. php/9330

\footnotetext{
Acknowledgments:

We thank Paul Senner and Patrice Kohl for research assistance and three anonymous reviewers for constructive input. This research was supported by funding from the U.S. Endowment on Forestry and Communities, the Knobloch Family Foundation, The Trust for Public Land, National Science Foundation Water Sustainability and Climate grant DEB 1038759, Long Term Ecological Research grant DEB 0832652, McIntire-Stennis Act MSN 168723, National Science Foundation Integrative Graduate Education and Research Training (IGERT) DGE-1144752, and National Science Foundation Graduate Research Fellowship Program DGE-1256259.
} 


\section{LITERATURE CITED}

American Farm Bureau Federation. 2017. Privacy and security principles for farm data. American Farm Bureau Federation, Washington, D.C., USA. [online] URL: http://www.fb.org/issues/ technology/data-privacy/privacy-and-security-principles-for-farmdata

Arbuckle Jr, J. G. 2013. Farmer attitudes toward proactive targeting of agricultural conservation programs. Society and Natural Resources 26(6):625-641. http://dx.doi.org/10.1080/089$\underline{41920.2012 .671450}$

Baldwin, R. F., and P. B. Leonard. 2015. Interacting social and environmental predictors for the spatial distribution of conservation lands. PLOS ONE 10(10):e0140540. http://dx.doi. org/10.1371/journal.pone.0140540

Biber, E. 2011. The problem of environmental monitoring. University of Colorado Law Review 83:1-82.

Brin, D. 1999. The transparent society: will technology force us to choose between privacy and freedom? Basic Books, Cambridge, Massachusetts, USA.

Bromley, D. W., and I. Hodge. 1990. Private property rights and presumptive policy entitlements: reconsidering the premises of rural policy. European Review of Agricultural Economics 17 (2):197-214. http://dx.doi.org/10.1093/erae/17.2.197

Butler, B. J., J. H. Hewes, P. Catanzaro, J. L. Greene, and M. A. Kilgore. 2010. Effects of federal, state, and local tax policies on family forest owners. U.S. Forest Service and University of Massachusetts Amherst, Family Forest Research Center, Amherst, Massachusetts, USA.

Byrd, K. B., A. R. Rissman, and A. M. Merenlender. 2009. Impacts of conservation easements for threat abatement and fire management in a rural oak woodland landscape. Landscape and Urban Planning 92(2):106-116. http://dx.doi.org/10.1016/j. landurbplan.2009.03.003

Cash, D. W., W. N. Adger, F. Berkes, P. Garden, L. Lebel, P. Olsson, L. Pritchard, and O. Young. 2006. Scale and cross-scale dynamics: governance and information in a multilevel world. Ecology and Society 11(2):8. http://dx.doi.org/10.5751/es-01759-110208

Chang, K. 2011. The 2010 national land trust census report. Land Trust Alliance, Washington, D.C., USA

Cheever, F., and J. Owley. 2015. Enhancing conservation options: an argument for statutory recognition of options to purchase conservation easements (OPCEs). Harvard Environmental Law Review 40:1-44. http://dx.doi.org/10.2139/ssrn.2598298

Claassen, R. 2014. 2014 Farm Act continues most previous trends in conservation. Amber Waves. 1A.

Doremus, H. 2003. A policy portfolio approach to biodiversity protection on private lands. Environmental Science and Policy 6 (3):217-232. http://dx.doi.org/10.1016/s1462-9011(03)00036-4

Doremus, H. 2008. Data gaps in natural resource management: sniffing for leaks along the information pipeline. Indiana Law Journal 83:407-463.

Dubay, S., C. Jacques, N. Golden, B. Kern, K. Mahoney, A. Norton, D. Patnayak, and T. Van Deelen. 2015. Environmental factors influencing white-tailed deer (Odocoileus virginianus) exposure to livestock pathogens in Wisconsin. PLOS ONE 10(6): e0128827. http://dx.doi.org/10.1371/journal.pone.0128827

Esty, D. C. 2004. Environmental protection in the information age. New York University Law Review 79:115-211.

Fairfax, S. K., L. Gwin, M. A. King, L. Raymond, and L. A. Watt. 2005. Buying nature: the limits of land acquisition as a conservation strategy, 1780-2004. MIT Press, Cambridge, Massachusetts, USA.

Gattuso, D. J. 2008. Conservation easements: the good, the bad, and the ugly. National Center for Public Policy Research, Washington, D.C., USA.

Global Open Data for Agriculture and Nutrition (GODAN). 2017. Statement of purpose. GODAN, Wallingford, UK. [online] URL: http://www.godan.info/pages/statement-purpose/

Halstuk, M. E., and B. F. Chamberlin. 2006. The Freedom of Information Act 1966-2006: a retrospective on the rise of privacy protection over the public interest in knowing what the government's up to. Communication Law and Policy 11 (4):511-564. http://dx.doi.org/10.1207/s15326926clp1104 3

Hartter, J., S. J. Ryan, C. A. MacKenzie, J. N. Parker, and C. A. Strasser. 2013. Spatially explicit data: stewardship and ethical challenges in science. PLoS Biology 11(9):e1001634. http://dx.doi. org/10.1371/journal.pbio.1001634

Hibbard, C. M., M. A. Kilgore, and P. V Ellefson. 2003. Property taxation of private forests in the United States: a national review. Journal of Forestry 101(3):44-49.

Hively, W. D., O. H. Devereux, and P. Claggett. 2013. Integrating federal and state data records to report progress in establishing agricultural conservation practices on Chesapeake Bay farms. Open-File Report 2013-1287. U.S. Geological Survey, Reston, Virginia, USA. [online] URL: https://pubs.er.usgs.gov/publication/ ofr20131287 http://dx.doi.org/10.3133/ofr20131287

Huff, T. D. 2015. Concern for information privacy among private forest landowners in Oregon. Journal of Forestry 113(3):287-290. http://dx.doi.org/10.5849/jof.14-079

Jacobs, H. M. 1995. The anti-environmental 'wise use' movement in America. Land Use Law and Zoning Digest 47(2):3-8. http:// dx.doi.org/10.1080/00947598.1995.10394698

Jansujwicz, J. S., A. J. K. Calhoun, J. E. Leahy, and R. J. Lilieholm. 2013. Using mixed methods to develop a frame-based private landowner typology. Society and Natural Resources 26 (8):945-961. http://dx.doi.org/10.1080/08941920.2012.729294

Kearns, F. R., M. Kelly, and K. A. Tuxen. 2003. Everything happens somewhere: using webGIS as a tool for sustainable natural resource management. Frontiers in Ecology and the Environment 1(10):541-548. http://dx.doi.org/10.1890/1540-9295 (2003)001[0541:ehsuwa]2.0.co;2

King, M. A., and S. K. Fairfax. 2006. Public accountability and conservation easements: learning from the Uniform Conservation Easement Act debates. Natural Resources Journal 46:65-130.

Lemos, M. C., and A. Agrawal. 2006. Environmental governance. Annual Review of Environment and Resources 31:297-325. http:// dx.doi.org/10.1146/annurev.energy.31.042605.135621 
Liddell, P., and J. Wilson. 2008-2012. Individual noncash contributions. Internal Revenue Service, Washington, D.C., USA

Locke, C. M., and A. R. Rissman. 2012. Unexpected co-benefits: forest connectivity and property tax incentives. Landscape and Urban Planning 104(3-4):418-425. http://dx.doi.org/10.1016/j. landurbplan.2011.11.022

L'Roe, A. W., and A. R. Rissman. 2017. Changes in Wisconsin's large private forests, 1999-2015: land ownership, conservation, and recreational access. Society and Natural Resources 30 (1):63-78. http://dx.doi.org/10.1080/08941920.2016.1180729

Ma, Z., B. J. Butler, P. F. Catanzaro, J. L. Greene, J. H. Hewes, M. A. Kilgore, D. B. Kittredge, and M. Tyrrell. 2014. The effectiveness of state preferential property tax programs in conserving forests: comparisons, measurements, and challenges. Land Use Policy 36:492-499. http://dx.doi.org/10.1016/j. landusepol.2013.09.016

Margules, C. R., and R. L. Pressey. 2000. Systematic conservation planning. Nature 405(6783):243-253. http://dx.doi.org/10.1038/35012251

Morris, A. W. 2008. Easing conservation? Conservation easements, public accountability and neoliberalism. Geoforum 39 (3):1215-1227. http://dx.doi.org/10.1016/j.geoforum.2006.10.004

Morris, A. W., and A. R. Rissman. 2010. Public access to information on private land conservation: tracking conservation easements. Wisconsin Law Review (6):1237-1282. http://dx.doi. org/10.2139/ssrn.2816156

Moynihan, D. P., and N. Landuyt. 2009. How do public organizations learn? Bridging cultural and structural perspectives. Public Administration Review 69(6):1097-1105. http://dx.doi.org/10.1111/j.1540-6210.2009.02067.x

National Conservation Easement Database (NCED). 2014. About the NCED. [online] URL: http://conservationeasement.us/ about

National Conservation Easement Database (NCED). $2015 b$. Frequently asked questions. [online] URL: http://conservationeasement. $\underline{\text { us/about/faqs }}$

National Conservation Easement Database (NCED). $2015 a$. National conservation easement database, July 2015 update. http:// conservationeasement.us/

Natural Resources Conservation Service (NRCS). 2011. The Freedom of Information Act; The Privacy Act; Section 1619 of the Farm Bill. NRCS, U.S. Department of Agriculture, Washington, D.C., USA. [online] URL: http://www.nrcs.usda.gov/Internet/ FSE DOCUMENTS/stelprdb1166472.pptx

Oksanen, M., and A. Kumpula. 2013. Transparency in conservation: rare species, secret files, and democracy. Environmental Politics 22(6):975-991. http://dx.doi. org/10.1080/09644016.2013.775726

Olmsted, J. L. 2011. The invisible forest: conservation easement databases and the end of the clandestine conservation of natural lands. Law and Contemporary Problems 74(4):51-82.

Olson, E. R., A. Treves, A. P. Wydeven, and S. J. Ventura. 2015. Landscape predictors of wolf attacks on bear-hunting dogs in Wisconsin, USA. Wildlife Research 41(7):584-597. http://dx.doi. org/10.1071/wr14043
Olsson, P., C. Folke, and F. Berkes. 2004. Adaptive comanagement for building resilience in social-ecological systems. Environmental Management 34(1):75-90. http://dx.doi.org/10.1007/s00267-003-0101-7

Owen, D. 2013. Mapping, modeling, and the fragmentation of environmental law. Utah Law Review 1:219-281.

Owley, J. 2006. The emergence of exacted conservation easements. Nebraska Law Review 84:1043-1112.

Owley, J. 2015. Keeping track of conservation. Ecology Law Quarterly 42:79-138.

Owley, J., and A. R. Rissman. 2016. Trends in private land conservation: increasing complexity, shifting conservation purposes and allowable private land uses. Land Use Policy 51:76-84. http://dx.doi.org/10.1016/j.landusepol.2015.10.026

Pickles, J. 2004. A history of spaces: cartographic reason, mapping, and the geo-coded world. Routledge, London, UK.

Pocewicz, A., J. M. Kiesecker, G. P. Jones, H. E. Copeland, J. Daline, and B. A. Mealor. 2011. Effectiveness of conservation easements for reducing development and maintaining biodiversity in sagebrush ecosystems. Biological Conservation 144 (1):567-574. http://dx.doi.org/10.1016/j.biocon.2010.10.012

Polasky, S., H. Doremus, and B. Rettig. 1997. Endangered species conservation on private land. Contemporary Economic Policy 15 (4):66-76. http://dx.doi.org/10.1111/j.1465-7287.1997.tb00490.x

Resource Renewal Institute. 2015. Defense of place. Resource Renewal Institute, Mill Valley, California, USA. [online] URL: http://www.rri.org/defenseofplace.php/index.html

Rickenbach, M., K. Zeuli, and E. Sturgess-Cleek. 2005. Despite failure: the emergence of "new" forest owners in private forest policy in Wisconsin, USA. Scandinavian Journal of Forest Research 20(6):503-513. http://dx.doi.org/10.1080/02827580500434806

Rissman, A. R., and V. Butsic. 2011. Land trust defense and enforcement of conserved areas. Conservation Letters 4(1):31-37. http://dx.doi.org/10.1111/j.1755-263x.2010.00136.x

Rissman, A. R., and A. M. Merenlender. 2008. The conservation contributions of conservation easements: analysis of the San Francisco Bay Area protected lands spatial database. Ecology and Society 13(1):40. http://dx.doi.org/10.5751/es-02329-130140

Rissman, A. R., and N. F. Sayre. 2012. Conservation outcomes and social relations: a comparative study of private ranchland conservation easements. Society and Natural Resources 25 (6):523-538. http://dx.doi.org/10.1080/08941920.2011.580419

Rissman, A. R., and R. Smail. 2015. Accounting for results: how conservation organizations report performance information. Environmental Management 55(4):916-929. http://dx.doi.org/10.1007/ $\underline{\mathrm{s} 00267-014-0435-3}$

Rutledge, R. 2012. Wisconsin program's open hunting land tough to find. Milwaukee Journal Sentinel, 16 September.

Sabor, A. A., V. C. Radeloff, R. E. McRoberts, M. Clayton, and S. I. Stewart. 2007. Adding uncertainty to forest inventory plot locations: effects on analyses using geospatial data. Canadian Journal of Forest Research 37(11):2313-2325. http://dx.doi. org/10.1139/x07-067 
Sandbrook, C. 2015. The social implications of using drones for biodiversity conservation. Ambio 44(Suppl 4):636-647. http://dx. doi.org/10.1007/s13280-015-0714-0

Snyder, S. A., and B. J. Butler. 2012. A national assessment of public recreational access on family forestlands in the United States. Journal of Forestry 110(6):318-327. http://dx.doi. org/10.5849/jof.11-090

Society of Environmental Journalists (SEJ). 2009. Obscure farm bill provision blacks out agricultural data. 25 February. [online] URL: http://www.sej.org/publications/watchdog-tipsheet/obscurefarm-bill-provision-blacks-out-agricultural-data

Steinzor, R. I., and L.-Y. Huang. 2012. Agricultural secrecy, going dark down on the farm: how legalized secrecy gives agribusiness a federally funded free ride. Center for Progressive Reform Briefing Paper No. 1213. University of Maryland Legal Studies Research Paper 2012-56. Baltimore, Maryland, USA.

United States Congress. 2008. Food, Conservation, and Energy Act of 2008., U.S. Congress, Washington, D.C., USA.

United States Department of Agriculture (USDA). 2016. Conservation reserve program statistics. USDA, Washington, D. C., USA. [online] URL: https://www.fsa.usda.gov/programsand-services/conservation-programs/reports-and-statistics/conservationreserve-program-statistics/index

United States Fish and Wildlife Service (USFWS). 2016. Habitat conservation plan (HCP) spatial data specifications. USFWS, Washington, D.C., USA.

United States Forest Service (USFS). 2015. Who owns America's trees, woods, and forests? Results from the U.S. Forest Service 2011-2013 National Woodland Owner Survey. NRS-INF-31-15. USFS, Washington, D.C., USA.

van der Wal, R., and K. Arts. 2015. Digital conservation: an introduction. Ambio 44(Suppl 4):517-521. http://dx.doi. org/10.1007/s13280-015-0701-5

Von Meyer, N. 2004. GIS and land records: the ArcGIS parcel data model. ESRI, Redlands, California, USA.

Wardropper, C. B., C. Chang, and A. R. Rissman. 2015. Fragmented water quality governance: constraints to spatial targeting for nutrient reduction in a Midwestern USA watershed. Landscape and Urban Planning 137:64-75. http://dx.doi. org/10.1016/j.landurbplan.2014.12.011

Wild, R., C. McLeod, and P. Valentine, editors. 2008. Sacred natural sites: guidelines for protected area managers. International Union for the Conservation of Nature, Gland, Switzerland.

Williams, K., S. A. Sader, C. Pryor, and F. Reed. 2006. Application of geospatial technology to monitor forest legacy conservation easements. Journal of Forestry 104(2):89-93.

Wisconsin Department of Natural Resources (WDNR). 2016. Forestry GIS data. WDNR, Madison, Wisconsin, USA. [online] URL: http://dnr.wi.gov/topic/forestmanagement/data.html 